\title{
Aplikasi Permintaan dan Pelacakan Surat Berbasis Android di Desa Sekaran Kecamatan Siman - Ponorogo
}

\author{
Aziz Musthafa ${ }^{1}$ \\ ${ }^{1)}$ Program Studi S1Teknik Informatika Universitas Darussalam Gontor \\ 1)aziz@unida.gontor.ac.id
}

\begin{abstract}
Abstrak
Begitu cepatnya perkembangan teknologi sangat mempengaruhi pelayanan masyarakat dilingkup desa. Akses cepat dan akurat dalam hal informasi khususnya permintaan dan pengambilan surat menjadi tugas dari Kepala Desa dan jajarannya. Saat ini masih menggunakan aplikasi yang berpusat didesa yang mengharuskan warga untuk datang ke kantor desa. Hal tersebut sudah bagus, namun dalam beberapa kasus harus kembali lagi dengan tangan kosong karena belum dapat tanda tangan kepala desa, tutup, atau sedang kegiatan desa. Selain itu belum ada kepastian kapan surat dapat diambil. Dengan adanya aplikasi permintaan dan pelacakan surat berbasis android, warga dapat melakukan permintaan surat berbasis android dan bila surat telah ditandatangi kepala desa warga dapat melihat informasi tersebut pada smartphone berbasis android. Dengan begitu proses pelayanan lebih optimal karena warga ke kantor desa hanya sekali yaitu saat surat sudah jadi. Dalam penelitian ini digunakan aspek desain aplikasi dan peningkatan kecepatan proses pelayanan desa dalam menguji aplikasi berjalan dengan baik atau tidak. Hasil yang dicapai melalui sebaran angket kepada 8 warga yang berbeda keluarga mendapatkan respon yang positif. Angket untuk kemudahan dan desain aplikasi dinilai sebesar 94,2\%. Sedangkan tingkat adanya peningkatan kecepatan proses pelayanan desa pada warga sebesar 95\%.
\end{abstract}

Kata kunci : Permintaan Surat, Android, Administrasi Desa

\section{PENDAHULUAN}

Tuntutan peningkatan kemampuan dalam mengelola data administrasi desa harus sejalan dengan perkembangan teknologi, sebagaimana desa sebagai bagian terkecil dari sistem pemerintahan administratif di Indonesia.

Dalam sistem pelayanan administrasi kependudukan di Desa Sekaran saat ini masih memanfaatkan aplikasi terpusat dikantor desa. Hal tersebut sudah bagus, namun dalam beberapa kasus pemohon harus kembali lagi dengan tangan kosong karena belum dapat tanda tangan kepala desa, tutup, atau sedang kegiatan desa. Selain itu belum ada kepastian kapan surat dapat diambil, oleh karena itu dalam beberapa kasus warga sering pulang pergi ke kantor desa namun surat masih belum jadi.

Berdasarkan penelitian yang telah dilakukan oleh Guntari \& Setiawan bahwa rancang bangun aplikasi pengelolaan surat di desa tanjung sudah dilakukan dan dapat membantu sekretaris mengelola surat masuk dalam penyimpanan surat dan dalam pembuatan proses surat keluar lebih cepat(Guntari \& Setiawan, 2016). Namun juga belum memunculkan solusi tentang pelacakan surat.

Android merupakan sebuah sistem operasi untuk perangkat mobile berbasis linux yang mencakup sistem operasi, middleware dan aplikasi. Android menyediakan platform yang terbuka bagi para pengembang untuk menciptakan aplikasi mereka(Safaat $\mathrm{H}$, 2011).

Dengan aplikasi permintaan dan pelacakan berbasis android berikutnya dikenal dengan SIMADES 2.0, warga dapat melakukan permintaan surat tanpa harus datang ke kantor desa. Apabila surat telah ditandatangi kepala desa, warga dapat melihat informasi tersebut di smartphone berbasis android mereka. Dengan begitu warga 
hanya sekali ke kantor desa yaitu saat surat telah siap diambil.

Selain itu yang mendasari mengapa aplikasi ini dalam bentuk mobile android adalah selain sebagian besar masyarakat pengguna ponsel pintar berbasis android juga dalam kondisi tertentu misalnya ketika dalam perjalanan, sedang diluar kota, sehingga kebutuhan akan ponsel pintar menjadi begitu penting(Muriyatmoko \& Abdullah, 2017).

\section{METODE PENELITIAN}

Penelitian dilakukan pada Desa Sekaran Kecamatan Siman Kabupaten Ponorogo selama bulan Januari-Agustus 2017. 8 jenis surat yaitu : Surat kelahiran, Surat SKCK, Surat Pindah, Surat Bepergian, Surat Status Nikah, Surat Ijin Keramaian, Surat Keterangan Miskin, dan Surat Keterangan.

Metode pembuatan aplikasi mengadopsi Siklus Hidup Perangkat Lunak, atau waterfall yaitu dengan melalui lima tahap yang berkesinambungan membentuk suatu siklus daur hidup perancangan perangkat lunak seperti pada Gambar 1 berikut :

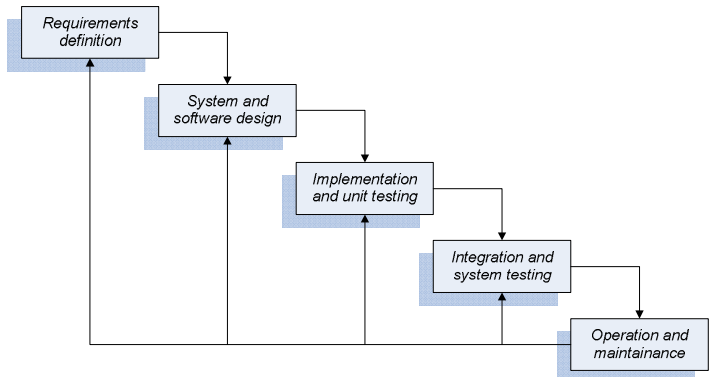

Gambar 1. Siklus Hidup Perangkat Lunak(Sommerville, 2011)

Penjelasan :

Requirements analysis and definition, mengumpulkan kebutuhan secara lengkap baik berupa data dari desa, penduduk, data berbagai jenis surat yang dibutuhkan maupun aplikasi yang digunakan dalam penelitian. Kemudian dianalisis dan didefinisikan kebutuhan yang harus dipenuhi oleh program yang akan dibangun. Fase ini harus dikerjakan secara lengkap untuk bisa menghasilkan desain yang lengkap.
System and software design, desain dikerjakan setelah kebutuhan selesai dikumpulkan secara lengkap. Desain disini meliputi :

1. Sitemap, Merupakan desain awal dari proses yang akan dikerjakan dalam pengembangan aplikasi.

2. Arsitektur aplikasi, rancangan didefinisikan dalam USE CASE, Activity Diagram dan rancangan layar. Use case merupakan deskripsi lengkap tentang bagaimana perangkat lunak berperilaku untuk pada aktornya(Nugroho, 2009), berikut merupakan gambaran use case :

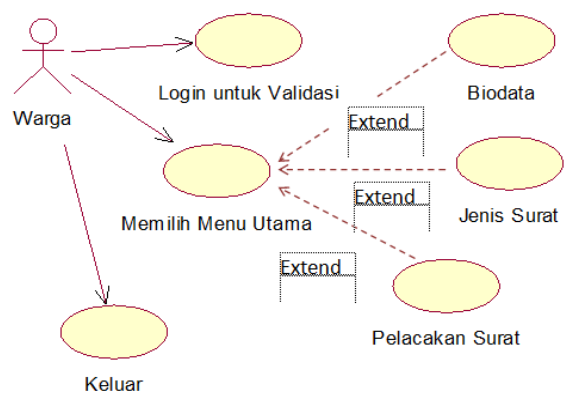

Gambar 2. Use Case Simades 2.0

3. Struktur data, rancangannya didefinisikan dalam Entity Relationship Diagram (ERD). ERD pada gambar 3 diambil dari database dari aplikasi yang sudah ada yaitu SIMADES 1.0 berbasis web.

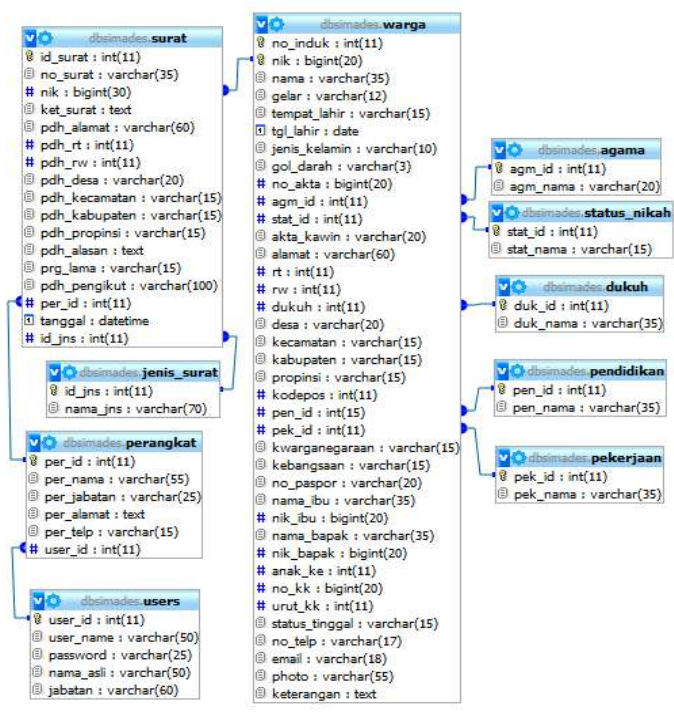

Gambar 3. ERD Aplikasi Permintaan dan Pelacakan Surat 
Implementation and unit testing, desain program diterjemahkan ke dalam kode-kode dengan menggunakan bahasa pemrograman Java. Pengembangan aplikasi berbasis Android disisi perangkat mobile dan pengelola disisi perangkat desa menggunakan HTML, PHP dan MySQL. Kemudian aplikasi yang dibangun langsung diujikan secara offline dan online.

Integration and system testing, penyatuan unit-unit aplikasi kemudian diuji secara keseluruhan (system testing). Testing langsung dilakukan di Desa Sekaran secara trial dengan disaksikan oleh perangkat desa pemegang administrasi sehingga mendapat masukan yang berarti bagi pengembangan aplikasi.

Operation and maintenance, memberi pelatihan dan wawasan perangkat desa mengenai cara mengoperasikan aplikasi di lingkungan desa dan melakukan pemeliharaan, seperti penyesuaian atau perubahan karena adaptasi dengan situasi sebenarnya.

\section{HASIL DAN PEMBAHASAN}

Karena pengujian aplikasi secara offline dan online sudah dilakukan bersama perangkat desa. Maka, penelitian ini menggunakan pendekatan kuantitatif dalam pengujian implementasi kewarga desa. Sehingga diharapkan mampu mengoptimalkan proses administrasi desa khususnya dalam hal surat menyurat yang berhubungan dengan warga Desa Sekaran.

Syarat minimum bagi pengguna aplikasi SIMADES 2.0 adalah :

1. Menguasai pemakaian aplikasi mobile berbasis android.

2. Sesuai digunakan pada layar diatas 4 inchi.

3. Sistem operasi yang digunakan harus andriod versi 4.0.1 / Ice Cream Sandwich atau diatasnya.

Design User Interface

Alur dan desain dari cara pakai aplikasi mobile SIMADES 2.0 akan dijelaskan pada tabel 1 berikut :
Tabel 1. Menu Aplikasi Mobile SIMADES 2.0

\begin{tabular}{|c|c|c|}
\hline No. & Nama Menu & Keterangan \\
\hline 1 & Selamat Datang & $\begin{array}{l}\text { Menampilkan } \\
\text { tampilan awal } \\
\text { pengguna }\end{array}$ \\
\hline 2 & Menu Login & $\begin{array}{l}\text { Menu Verifikasi } \\
\text { Masuk Warga }\end{array}$ \\
\hline 3 & Menu Utama & 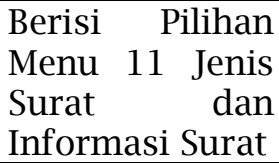 \\
\hline 4 & Menu Surat & $\begin{array}{l}\text { Berisi Opsi } \\
\text { Permintaan } \\
\text { Surat dimana } \\
\text { warga mengisi } \\
\text { data keperluan } \\
\text { surat }\end{array}$ \\
\hline 5 & Pelacakan & $\begin{array}{l}\text { Berisi informasi } \\
\text { kondisi surat, } \\
\text { terdapat } \\
\text { keterangan } \\
\text { bahwa surat } \\
\text { telah siap } \\
\text { diambil atau } \\
\text { belum }\end{array}$ \\
\hline 6 & Menu Biodata & $\begin{array}{ll}\text { Berisi data } \\
\text { penduduk desa }\end{array}$ \\
\hline
\end{tabular}

Berikut detail desain dari tabel, gambar 4 yaitu layar tampilan awal saat aplikasi pertama kali dijalankan. Halaman tersebut menyediakan hanya sebagai splash Screen.

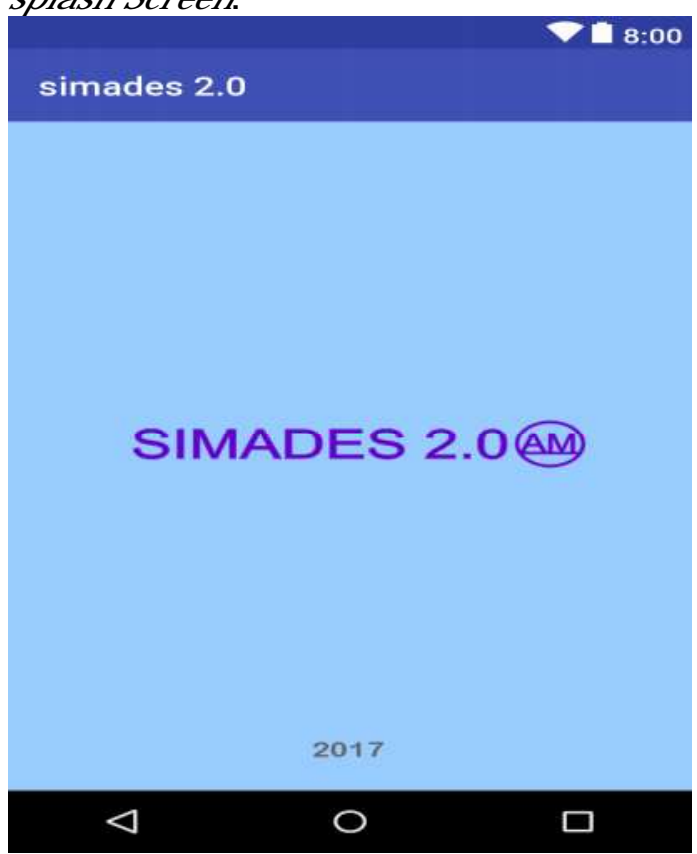

Gambar 4. Halaman Awal SIMADES 2.0 
Gambar 5 merupakan halaman login yang diperuntukkan untuk warga Desa Sekaran. Dihalaman ini warga wajib menginputkan id user dan password untuk menuju pada menu utama. Id user dapat menggunakan nama awal dari warga, sedangkan password sementara menggunakan tanggal lahir warga.

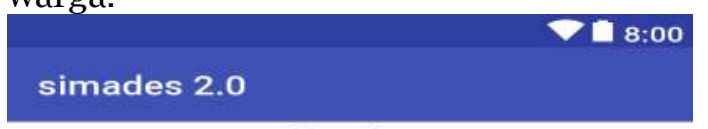

$$
\text { .: Login : . }
$$

User Id

\begin{tabular}{l} 
Password \\
CLEAR LOGIN \\
\hline
\end{tabular}

\section{$\triangleleft$}

\section{○}

$\square$

Gambar 5. Halaman Login

Gambar 6 merupakan halaman menu utama yang menyediakan tombol menu biodata warga, 8 tombol menu jenis surat.

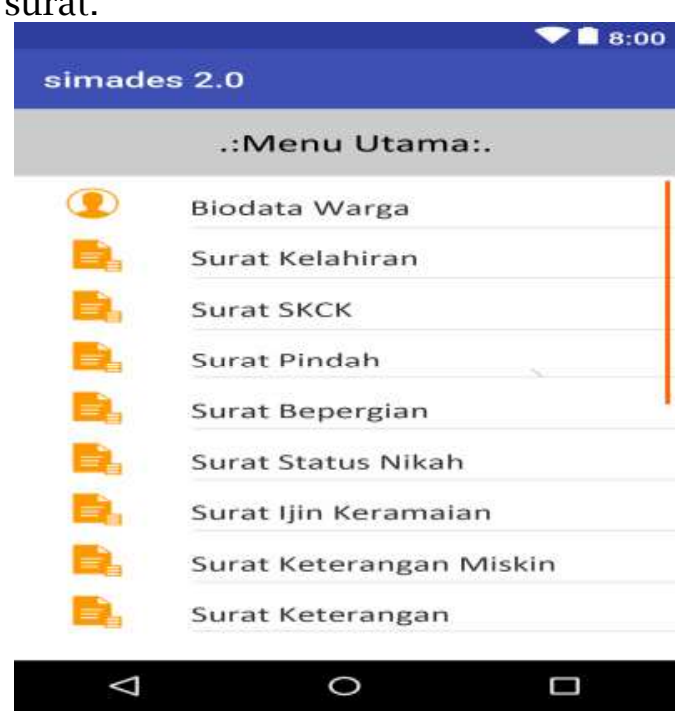

Gambar 6. Halaman Menu Utama
Selain itu bila scrollbar digeser kebawah tersedia menu traking surat dan tombol keluar aplikasi sesuai gambar 7 .

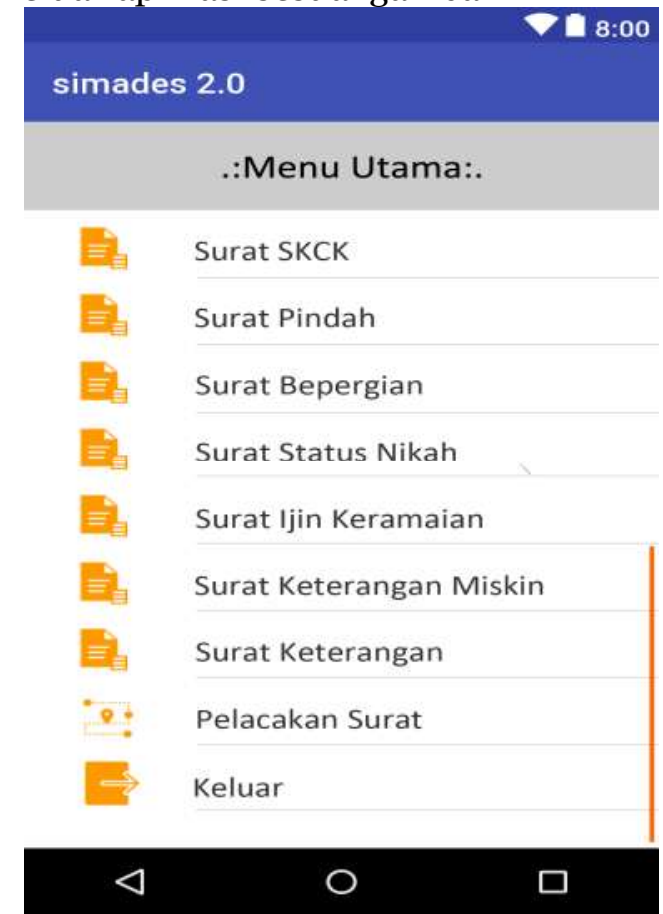

Gambar 7. Halaman Menu Utama 2

Pada menu utama terdapat tombol Biodata Warga. Gambar 8 merupakan halaman biodata warga sesuai dengan validasi saat login.

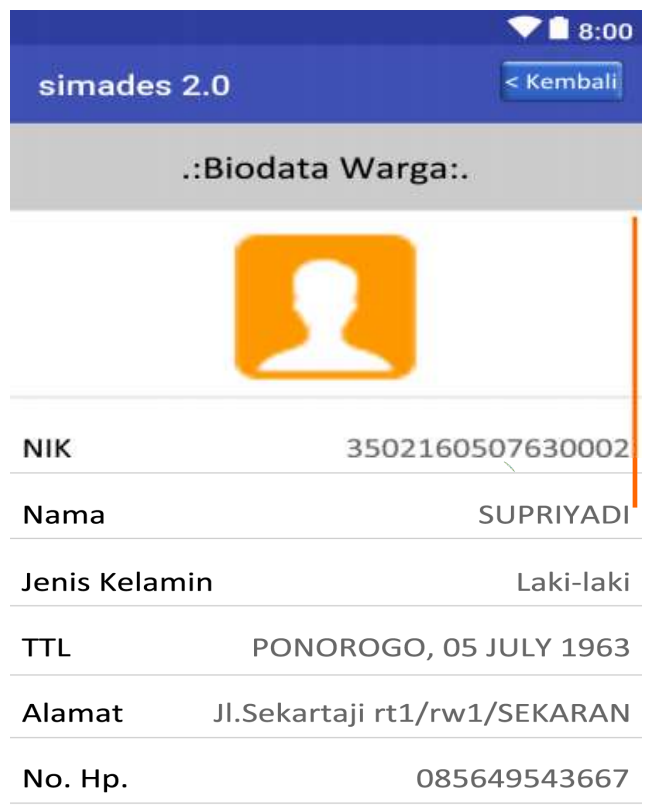
$\checkmark$ O
$\square$

Gambar 8 Biodata Warga 


\begin{tabular}{|c|c|}
\hline \multicolumn{2}{|c|}{$\begin{array}{l}\text { Gambar } 9 \text { merupakan mer } \\
\text { berdasarkan pilihan jenis surc } \\
\text { Dihalaman ini warga diwajibkan mengi } \\
\text { keperluan atau isian lainnya sesu } \\
\text { dengan kriteria surat yang dipilih. }\end{array}$} \\
\hline \multicolumn{2}{|l|}{ simades 2.0} \\
\hline \multicolumn{2}{|c|}{.:Permintaan Surat SKCK:. } \\
\hline NIK & 3502160507630002 \\
\hline Nama & SUPRIYADI \\
\hline Jenis Kelamin & Laki-laki \\
\hline$T T L$ & PONOROGO, 05 JULY 1963 \\
\hline Alamat & II.Sekartaji rt1/rw1/SEKARAN \\
\hline Pekerjaan & Wira Swasta \\
\hline Keperluan & \\
\hline
\end{tabular}

Kirim

\section{$\triangleleft$} ○ $\square$

Gambar 9. Permintaan Surat SKCK Gambar 10 Merupakan halaman pelacakan surat yaitu informasi apakah surat yang telah diminta sudah ditandatangi, perlu pengurusan langsung ke desa, atau belum diproses.

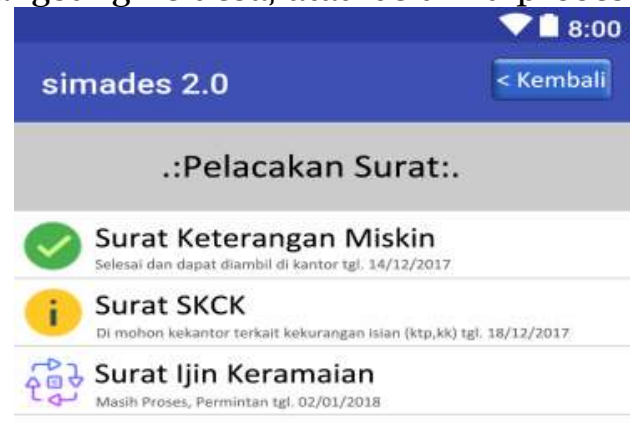

$\triangleleft$ O $\square$

Gambar 10. Pelacakan Surat
Hasil Pengujian

Hasil yang diperoleh setelah implementasi aplikasi ini terdapat peningkatan teknologi dan kemudahan dalam hal pelayanan administrasi khususnya surat-menyurat. Hal ini terbukti dari sebaran angket kepada 8 warga desa yang memanfaatkan aplikasi SIMADES 2.0 berbasis android sebagai media permintaan dan pelacakan surat warga. Warga yang mengisi angket tidak ada hubungan keluarga antara satu dengan yang lain.

Sebagai pengguna aplikasi, warga desa memberikan dukungan sangat baik terhadap pelaksaan implementasi SIMADES 2.0 berbasis android yaitu terlihat dari hasil sebaran angket tentang tingkat kemudahan penggunaan dan desain aplikasi sebanyak 94,2\%. Hal ini merupakan angka yang tinggi sehingga dapat disimpulkan aplikasi yang dibuat, mudah di operasikan oleh warga.

Sedangkan hasil sebaran angket tentang adanya peningkatan kecepatan proses pelayanan desa Sekaran sebanyak 95\%.

Dari hasil tersebut dapat disimpulkan bahwa aplikasi SIMADES 2.0 berbasis android diperlukan bagi Desa Sekaran khususnya bagian pelayanan administrasi dibagian surat menyurat. Pada akhir penelitian, juga terdapat hasil sebaran angket tentang tingkat keberlanjutan aplikasi di Desa Sekaran dalam hal pemeliharaan untuk aplikasi SIMADES 2.0 berbasis android sebanyak 92,9\%. Hal tersebut membuktikan bahwa keinginan masyarakat khususnya Desa Sekaran atas keberlanjutan pengembangan aplikasi dalam hal teknologi maupun yang lain terus dinantikan.

\section{KESIMPULAN}

Kesimpulan dari hasil implementasi dan pengujian aplikasi SIMADES 2.0 berbasis android dengan menggunakan angket oleh warga desa sebanyak 8 orang dari 8 keluarga yang berbeda. Dengan hasil yang didapatkan dimana tingkat kemudahan penggunaan dan desain aplikasi sebanyak 94,2\%. Sedangkan tingkat adanya peningkatan 
kecepatan proses pelayanan desa sejak implementasi aplikasi sebanyak 95\%.

SARAN

Dalam hal perancangan, pembuatan , hingga implementasi tentunya aplikasi ini masih banyak kekurangan yang dapat menjadikan pengembangan ketahap selanjutnya. Sedangkan saran yang dapat disampaikan sebagai berikut :

1. Menu jenis surat belum dinamis sesuai dengan keinginan perangkat.

2. Penambahan jenis surat baik secara otomatis atau manual perlu utuk dilakukan.

3. Pelatihan kepada warga masih belum bisa menyeluruh

4. Pengembangan platform kedepannya dapat diimpementasikan dalam platform Windows Phone maupun los.

\section{DAFTAR PUSTAKA}

Guntari, R., \& Setiawan, R. (2016). Rancang bangun Aplikasi Pengelolaan Surat di Desa Tanjung
Kamuning. Jurnal Algoritma Sekolah Tinggi Teknologi Garut, 13(1), 269-274.

Muriyatmoko, D., \& Abdullah, A. F. (2017). Aplikasi Tamrin Lughoh

(Pembelajaran Bahasa Arab) Pondok

Modern Darussalam Gontor

Berbasis Mobile. Semnasteknomedia Online, 5(1), 4-5-49. Retrieved from http://ojs.amikom.ac.id/index.php/ semnasteknomedia/article/view/17 45

Nugroho, A. (2009). Rekayasa Perangkat Lunak Menggunakan UML dan Java. Bandung: Andi.

Safaat H, N. (2011). Pemrograman Aplikasi Mobile Smartphone dan Tablet PC Berbasis Android. Bandung: INFORMATIKA.

Sommerville, I. (2011). Software Engineering (Rekayasa Perangkat Lunak). Jakarta: Erlangga. 